\title{
Distribution of microbial biomass, production, respiration, dissolved organic carbon and factors controlling bacterial production across a geostrophic front (Almeria-Oran, SW Mediterranean Sea)
}

\author{
France Van Wambeke ${ }^{1, *}$, Dominique Lefèvre ${ }^{2}$, Louis Prieur ${ }^{3}$, Richard Sempéré ${ }^{1}$, \\ Micheline Bianchi ${ }^{1}$, Kadija Oubelkheir ${ }^{3}$, Flavienne Bruyant ${ }^{3}$ \\ ${ }^{1}$ Laboratoire de Microbiologie Marine, CNRS, UMR 6117, Centre d'Océanologie de Marseille, Case 907, Campus de Luminy, \\ 13288 Marseille Cedex 9, France \\ ${ }^{2}$ Laboratoire d'Océanographie et de Biogéochimie, UMR 6535, Centre d'Océanologie de Marseille, Case 901, \\ Campus de Luminy, 13288 Marseille Cedex 9, France \\ ${ }^{3}$ Laboratoire d'Océanographie de Villefranche, CNRS, UMR 7093, Observatoire Océanologique, BP 08, \\ 06230 Villefranche-sur-Mer, France
}

\begin{abstract}
Microbial distribution and activities were examined in relation to the hydrodynamic conditions in the Almeria-Oran frontal area (AOF), SW Mediterranean Sea, during winter. The main objectives were to explore factors limiting bacterial growth and activities (production, ectoenzymatic activity, utilization and respiration of amino acids) in regard to dissolved organic carbon (DOC) stocks and lability in different parts of the Almeria-Oran front-jet system. The vertical distribution of total chl $a$, bacterial abundance and production reflected the density profiles, with a deepening of the top of the pycnocline from 25 (front) to $120 \mathrm{~m}$ (gyre). At the frontal site, most bacterial production was concentrated within the first $20 \mathrm{~m}$ (up to $19.8 \mathrm{nmol} \mathrm{C}^{-1} \mathrm{~h}^{-1}$ ), at the boundary between the jet and Mediterranean waters, whereas bacterial abundance peaked in a wider layer $(40 \mathrm{~m})$ in the jet core (up to $15 \times 10^{5}$ bacteria $\mathrm{ml}^{-1}$ ). Integrated bacterial production ranged from 5.7 to $17.9 \mathrm{mmol} \mathrm{C} \mathrm{m}^{-2} \mathrm{~d}^{-1}$ in the 0 to $200 \mathrm{~m}$ layer in the meander of the Atlantic jet and in its associated anticyclonic gyre, compared to 4.3 to $5.8 \mathrm{mmol} \mathrm{C} \mathrm{m}^{-2} \mathrm{~d}^{-1}$ in typical Mediterranean waters. Heterotrophic bacteria were limited by phosphorus in the surface layers of the front and Mediterranean waters. Shipboard experiments using $<0.8 \mu \mathrm{m}$ filtered seawater incubated in the dark showed a high growth potential of the heterotrophic bacteria within the jet and the jet-gyre boundaries. Increased DOC accumulation (from 12 to $21 \mu \mathrm{M}$ excess DOC = surface minus deep refractory DOC) occurred at the jet-gyre boundaries. From the jet towards the gyre, the decrease in potential ectoaminopeptidase activity was less than that of bacterial production, indicating that there was a greater dependence on polymeric DOC. Only the typical Mediterranean site, outside of the jet and gyre influences, was clearly net heterotrophic.
\end{abstract}

KEY WORDS: Winter - Western Mediterranean - Almeria-Oran front - Bacterial production · Ectoaminopeptidase $\cdot$ Respiration $\cdot$ Bacterial limitation $\cdot$ Dissolved organic carbon

Resale or republication not permitted without written consent of the publisher

\section{INTRODUCTION}

Mesoscale discontinuities clearly influence biological activity and the fate of organic carbon in the oceans (Ducklow 1984, Karrash et al. 1996, Legendre \& Ras- soulzadegan 1996). Their impact has been observed in the Mediterranean Sea (Moran et al. 2001 and references therein). In the Western Mediterranean Sea, Atlantic surface waters enter through the Gibraltar Strait and flow permanently, on an annual scale, as 
a jet of ca. $40 \mathrm{~km}$ width. The convergence of the geostrophic jet originating in the Atlantic Ocean with the more saline Mediterranean water results in the formation of a front, located between Almeria (Spain) and Oran (Algeria), and named the Almeria-Oran front (AOF). The jet creates 2 meanders in the Alboran Sea, both associated with the anticyclonic gyres of Atlantic water south of the jet, whereas north of the jet, Mediterranean waters are without a clear, permanent dynamic flow. This area of restricted horizontal dimension (ca. $100 \mathrm{~km}$ ), displays strong gradients and intense flows and velocities. It has been described in terms of dynamics and fertilization (Prieur \& Sournia 1994, Allen et al. 2001, Baldacci et al, 2001, Fielding et al. 2001, Rodriguez et al. 2001 and references therein) and thus, is suitable for mesoscale studies on physicalbiological coupling.

There are 2 types of flow associated with the geostrophic front: the main current along the front (primary circulation) and a slow vertical and horizontal movement across the jet (secondary circulation). The biological consequence is fertilization, which stimulates primary production in the frontal waters and adjacent areas. This is associated with the subsequent downwelling of biomass within the anticyclonic gyre of Atlantic waters (Claustre et al. 1994, Prieur \& Sournia 1994, Videau et al. 1994). A previous spring cruise revealed that $50 \%$ of the 0 to $150 \mathrm{~m}$ chl a stock was found inside the jet area, covering only $1 / 5$ of the eastern part of the Alboran Sea (Prieur \& Sournia 1994). The increase in primary production coupled with secondary circulation modifies secondary production and microbial food webs (Fernandez et al. 1994, Thibault et al. 1994). The magnitude and quality of dissolved organic matter produced is, in turn, notably influenced by the physical structure (Gérin \& Goutx 1994, Claustre et al. 2000, Grout et al. 2001, Sempéré et al. 2003) and drives the variability of bacterial production.

Most papers dealing with hydrodynamic discontinuities generally describe the horizontal and vertical distribution of bacterial standing stocks and production as a function of phytoplankton structure and activity in relation to different mesoscale regimes (Ducklow 1986, Lochte \& Pfannkuche 1987, Fernandez et al. 1994, Karrash et al. 1996, Bode et al. 2001, Moran et al. 2001). However, studies on heterotrophic activity (such as polymer hydrolysis, monomer uptake, respiration), along with determinations of the availability of organic matter to bacteria (stocks, lability, and quality), can help us to understand the relationships between the source and fate of organic matter. Relationships between bacterial production and ectoenzymatic activity have been studied in marine discontinuities influenced by land inputs, where eutrophication is generally very high (e.g. fjords or river plumes; Karner et al. 1992, Hoppe et al. 1998), but these situations differ from the trophic gradients encountered in open-sea discontinuities. The aim of this study was to describe heterotrophic bacterioplankton activities in relation to different qualities and stocks of resources (DOC, phytoplankton) across the geostrophic Almeria-Oran front. We studied 8 sites representative of the main frontal zone and adjacent waters within the Mediterranean waters, front, jet and Atlantic anticyclonic gyre (AAG). Vertical profiles of the stocks (bacteria, chl $a$, heterotrophic nanoflagellates, organic matter)
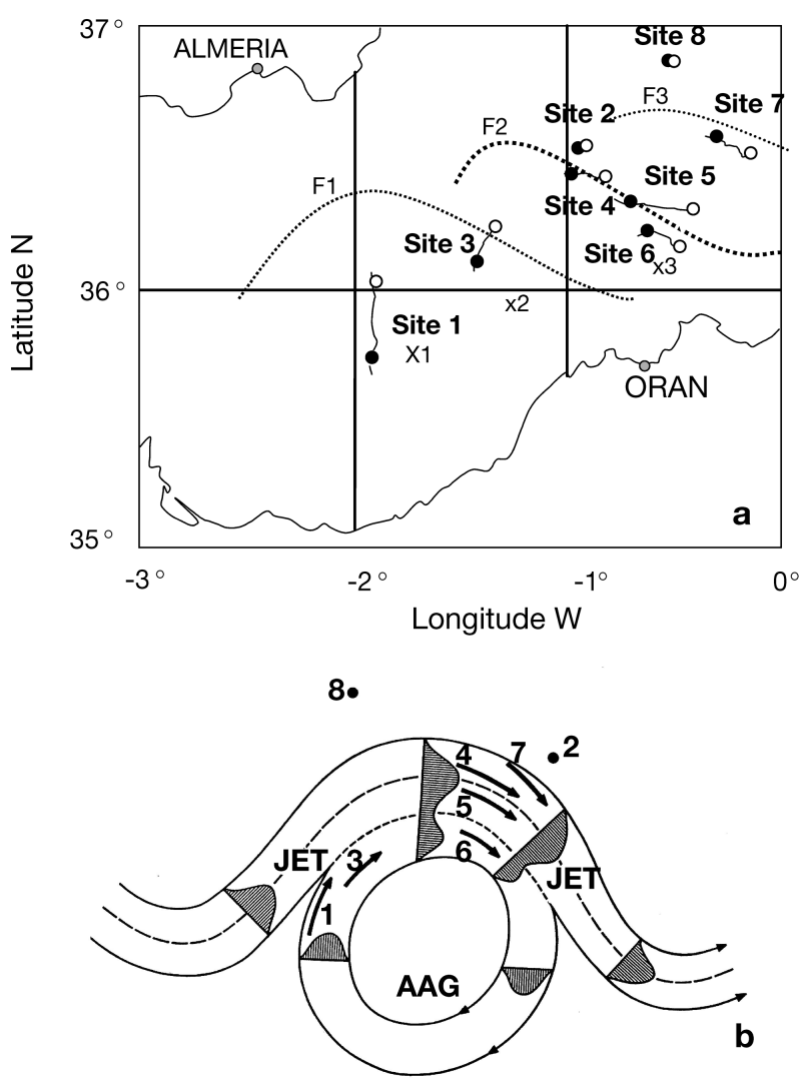

Fig. 1. (a) Geographical location of sites studied in the Alboran Sea (SW Mediterranean) during Leg 2 of the Almofront 2 cruise. Lines indicate the ship route, following the drift of sediment traps during the occupation of each site ( $36 \mathrm{~h}$ ). Marked circles indicate the 2 stations sampled at noon on the first and the second day, which were chosen for phytoplanktonic/ bacterial/TOC parameters. During Leg 2, the meander jet system moved eastward by ca. $90 \mathrm{~km}$, as indicated by the successive positions of the surface density front $(\mathrm{F})$ and the center of the Atlantic anticyclonic gyre (AAG; X): F1/X1 represent 1-20 December 1997 (end of Leg 1), F2/X2 25-30 December 1997 (Sites 1 to 3), and F3/X3 5-10 January 1998 (Sites 6 to 8). (b) Idealized scheme of the hydrological structure, positioning sites in relation to the meander of the Atlantic current and the Atlantic anticyclonic gyre. Shaded areas are proportional to the horizontal current velocity 
and fluxes (primary and bacterial production, net community production, dark community respiration, utilization of amino acids, ectoaminopeptidase activity) were determined for the different sites. In addition to these in situ measurements, on-board experiments were performed to determine the bacterial growth capacity and factors limiting bacterial production (enrichment experiments).

\section{MATERIALS AND METHODS}

Sample collection. The Almofront 2 cruise (30 November 1997 to 16 January 1998) was dedicated to studying the winter dynamics and physical properties of the Almeria-Oran geostrophic front (Alboran Sea, SW Mediterranean) and the associated biological processes. The first leg (30 November to 22 December) was devoted to a synoptic description (dynamical, hydrological and biological) of the area (Sempéré et al. 2003). The aim of the second leg (24 December 1997 to 16 January 1998) was to study the biological processes which were associated with the identified physical structures, using a sampling strategy applied on a previous cruise in May 1991 (Almofront 1; Prieur \& Sournia 1994). Following an intensive $12 \mathrm{~h}$ survey of the area (using continuous thermosalinometer and vessel mounted ADCP [Acoustic Doppler Current Profiler], RDI Instruments, $75 \mathrm{kHz}$ ), 8 sites were chosen. Satellite images focusing on the position of the Atlantic current and associated gyres helped us to choose the location of the sites according to hydrodynamic structure (Fig. 1a). Each site was subsequently identified within the frame of the idealized dynamic structure described in the 'Results' (Fig. 1b). The site survey began by immersing a drifting line with 2 sediment traps to 100 and $300 \mathrm{~m}$, this was then followed by the ship for $36 \mathrm{~h}$ (Fig 1a; Table 1). During this period (from 04:00 $\mathrm{h}$ on Day 1 to 16:00 h on Day 2), conductivity temperature depth (CTD) casts were carried out every $3 \mathrm{~h}$. The ship's drift during the site survey is shown in Fig. 1a.

To estimate bacterial dynamics, replicate profiles were sampled over 2 consecutive days around noon (Fig. 1a). Samples were collected using a 911 plus SBE CTD rosette, equipped with 121 Niskin bottles; $500 \mathrm{ml}$ samples were drawn into dark polycarbonate bottles rinsed 3 times before filling. Subsamples were taken for measurements of bacteria and flagellate stocks and bacterial production. All activity measurements began within $0.5 \mathrm{~h}$ of sample collection. From the same rosette, 2 bottles of seawater (2.8 l) were collected and filtered using GF/F filters for pigment analysis and determination of particulate organic carbon (POC); $10 \mathrm{ml}$ sub-samples were collected into glass ampoules for total organic carbon (TOC) analysis and 11 dark glass bottles were filled for primary production estimates. Only samples for oxygen measurements came from a different cast, taken at each site before sunrise on the second day.

Characterization of organic matter. TOC concentration was measured by high-temperature catalytic oxidation using a Shimadzu TOC-5000 analyzer.

Table 1. Localisation of the sites, sampling dates for the noon conductivity temperature depth (CTD) casts, geographic positions of the CTD casts and corresponding depths $(\mathrm{m})$ where density $(\sigma)$ is 27.5 and $28.5 \mathrm{~kg} \mathrm{~m}^{-3}$. AOF: Almeria-Oran frontal area; AAG: Atlantic anticyclonic gyre

\begin{tabular}{|c|c|c|c|c|c|c|}
\hline $\begin{array}{l}\text { Localisation } \\
\text { within AOF structure }\end{array}$ & Site & $\begin{array}{c}\text { Date }(\mathrm{dd} / \mathrm{mm} / \mathrm{yy}) \\
\text { and time }\end{array}$ & Latitude & Longitude & $\begin{array}{l}\text { Depth }(\mathrm{n} \\
\sigma=27.5\end{array}$ & $\begin{array}{l}\text {, where } \\
\sigma=28.5\end{array}$ \\
\hline Mediterranean & 8 & $\begin{array}{l}12 / 01 / 9811: 40 \\
13 / 01 / 9811: 30\end{array}$ & $\begin{array}{l}36^{\circ} 51^{\prime} \\
36^{\circ} 52^{\prime}\end{array}$ & $\begin{array}{l}-0^{\circ} 31^{\prime} \\
-0^{\circ} 31^{\prime}\end{array}$ & - & $\begin{array}{l}57 \\
57\end{array}$ \\
\hline $\begin{array}{l}\text { Mediterranean, jet } \\
\text { influenced }\end{array}$ & 2 & $\begin{array}{l}27 / 12 / 9711: 45 \\
28 / 12 / 9711: 45\end{array}$ & $\begin{array}{l}36^{\circ} 32^{\prime} \\
36^{\circ} 33^{\prime}\end{array}$ & $\begin{array}{l}-0^{\circ} 57^{\prime} \\
-0^{\circ} 56^{\prime}\end{array}$ & $\begin{array}{l}- \\
-\end{array}$ & $\begin{array}{l}62 \\
62\end{array}$ \\
\hline Front & 7 & $\begin{array}{l}\text { 08/01/98 } 11: 30 \\
09 / 01 / 9811: 40\end{array}$ & $\begin{array}{l}36^{\circ} 34^{\prime} \\
36^{\circ} 30^{\prime}\end{array}$ & $\begin{array}{l}-0^{\circ} 18^{\prime} \\
-0^{\circ} 08^{\prime}\end{array}$ & $\begin{array}{l}21 \\
32\end{array}$ & $\begin{array}{l}82 \\
97\end{array}$ \\
\hline Center jet & 4 & $\begin{array}{l}02 / 01 / 9811: 35 \\
03 / 01 / 9811: 10\end{array}$ & $\begin{array}{l}36^{\circ} 26^{\prime} \\
36^{\circ} 25^{\prime}\end{array}$ & $\begin{array}{l}-0^{\circ} 59^{\prime} \\
-0^{\circ} 49^{\prime}\end{array}$ & $\begin{array}{l}52 \\
57\end{array}$ & $\begin{array}{r}87 \\
107\end{array}$ \\
\hline South jet AAG & 1 & $\begin{array}{l}25 / 12 / 9711: 50 \\
26 / 12 / 9711: 35\end{array}$ & $\begin{array}{l}35^{\circ} 44^{\prime} \\
36^{\circ} 02^{\prime}\end{array}$ & $\begin{array}{l}-1^{\circ} 55^{\prime} \\
-1^{\circ} 55^{\prime}\end{array}$ & $\begin{array}{l}87 \\
77\end{array}$ & $\begin{array}{l}132 \\
127\end{array}$ \\
\hline South jet AAG & 5 & $\begin{array}{l}04 / 01 / 9811: 40 \\
05 / 01 / 9811: 05\end{array}$ & $\begin{array}{l}36^{\circ} 19^{\prime} \\
36^{\circ} 18^{\prime}\end{array}$ & $\begin{array}{l}-0^{\circ} 43^{\prime} \\
-0^{\circ} 25^{\prime}\end{array}$ & $\begin{array}{r}92 \\
102\end{array}$ & $\begin{array}{l}122 \\
137\end{array}$ \\
\hline AAG & 3 & $\begin{array}{l}29 / 12 / 9711: 45 \\
30 / 12 / 9711: 50\end{array}$ & $\begin{array}{l}36^{\circ} 06^{\prime} \\
36^{\circ} 14^{\prime}\end{array}$ & $\begin{array}{l}-1^{\circ} 26^{\prime} \\
-1^{\circ} 21^{\prime}\end{array}$ & $\begin{array}{l}117 \\
112\end{array}$ & $\begin{array}{l}157 \\
147\end{array}$ \\
\hline AAG & 6 & $\begin{array}{l}06 / 01 / 9811: 25 \\
07 / 01 / 9811: 25\end{array}$ & $\begin{array}{l}36^{\circ} 12^{\prime} \\
36^{\circ} 09^{\prime}\end{array}$ & $\begin{array}{l}-0^{\circ} 38^{\prime} \\
-0^{\circ} 29^{\prime}\end{array}$ & $\begin{array}{l}122 \\
122\end{array}$ & $\begin{array}{l}157 \\
162\end{array}$ \\
\hline
\end{tabular}


The analytical procedure is detailed in Sempéré et al. (2003). The instrument blank averaged $10 \pm 3 \mu \mathrm{M} \mathrm{C}$ (mean $\pm \mathrm{SD}$ ), analytical precision of the procedure is, on average, $\pm 3 \%$. DOC was calculated as TOC minus POC.

POC and total chl a (Tchl a) were determined using a LECO 900 analyzer and high performance liquid chromatography, respectively, as described in Claustre et al. (2000). Total chl a equals divinyl chl $a+\operatorname{chl} a$, and the analytical precision of the estimate is $\pm 5 \mathrm{ng} \mathrm{l}^{-1}$ (SD).

Bacteria and flagellate abundance. Subsamples $(20 \mathrm{ml})$ were fixed with filtered, buffered formalin solution ( $2 \%$ final concentration) and stored at $4{ }^{\circ} \mathrm{C}$. Within $12 \mathrm{~h}, 8$ to $20 \mathrm{ml}$ of the subsamples were stained with DAPI (2500 $\mathrm{g} \mathrm{l}^{-1}$ final conc.) and filtered onto $0.2 \mu \mathrm{m}$ dark polycarbonate filters; they were then stored at $-20^{\circ} \mathrm{C}$. Bacterial abundance was determined by epifluorescence microscope coupled to an image-analyzer system (Van Wambeke 1995). Prochlorophytes were counted using flow cytometry, and their abundance (up to $30 \times 10^{3} \mathrm{ml}^{-1}$ at Sites 2 and 8 , S. Jacquet pers. comm.) was subtracted from the epifluorescence counts. Finally, bacterial biomass was estimated using a conversion factor of $15 \mathrm{fg} \mathrm{C}$ per cell (Fukuda et al. 1998, Caron et al. 1999).

Heterotrophic nanoflagellates (HNAN) were counted in 5 size classes (ellipsoid forms) from 3 to $85 \mu^{3}$ by looking at $15 \mathrm{~mm}$ random strips on the same slides used for bacterial abundance determinations (Christaki et al. 1999). Variability between the random strips was ca. $20 \%$. HNAN carbon biomass was estimated from abundance and biovolume assuming a conver-

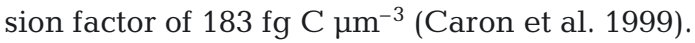

Oxygen fluxes. Net community production (NCP) and dark community respiration rates (DCR) were determined from variations in $\mathrm{O}_{2}$ concentration following $24 \mathrm{~h}$ incubations. Samples were incubated in borosilicate-calibrated bottles; 1 set of quadruplicates of the initial samples were fixed with Winkler reagents, and 2 sets of quadruplicates were incubated in the dark and in in situ-simulated light conditions (running surface-seawater baths covered with neutral screens varying from 50 to $1 \%$ incident light) prior to being fixed. Initial and incubated samples were titrated together using an automatic titrator as described by Williams \& Jenkinson (1982). Values outside the mean \pm SD range were discarded.

Primary production. Primary production was calculated using photosynthetic parameters estimated from photosynthesis-irradiance ( $\mathrm{P}$ vs E) curves measured at selected levels. Following $\mathrm{NaH}^{14} \mathrm{CO}_{3}$ inoculation, samples were exposed to different light intensities in a radial photosynthetron (Bruyant 2002). The P vs E parameters (saturation parameter, maximum chloro- phyll-specific carbon-fixation rate, chlorophyll-specific photosynthetic efficiency), together with the depth profiles of photosynthetically available radiation (PAR), Tchl $a$, and daily irradiance, were used to estimate the daily rates of primary production in the euphotic zone according to the model of Morel et al. (1996). The accuracy of determining photosynthetic parameters has been studied previously (Babin et al. 1994) and the standard deviation for maximum chlorophyll-specific carbon-fixation rates and chlorophyllspecific photosynthetic efficiency is ca. $8 \%$.

Heterotrophic bacterial production. Heterotrophic bacterial production (BP) was measured using ${ }^{3} \mathrm{H}-$ leucine incorporation into proteins. $\left[4,5-{ }^{3} \mathrm{H}\right]$-leucine (specific activity $112 \mathrm{Ci} \mathrm{mmol}^{-1}$, Amersham) and unlabelled leucine were added to $20 \mathrm{ml}$ samples giving final concentrations of 1.2 and $19 \mathrm{nM}$, respectively. Duplicate samples and 1 formalin-killed blank were incubated in the dark at in situ temperature $\left( \pm 2^{\circ} \mathrm{C}\right)$ for $2 \mathrm{~h}$, during the linear period of incorporation. Samples were then fixed with formalin ( $1 \%$ final conc.) and filtered onto $0.2 \mu \mathrm{m}$ filters (mixed cellulose ester, Advantec MFS). Each filter was rinsed 3 times with $5 \%$ trichloroacetic acid and stored frozen. Upon return to the laboratory, the filters were dissolved in $1 \mathrm{ml}$ ethyl acetate and radioassayed in a Packard 1600 scintillation counter. Using concentration kinetics, we checked that no isotopic dilution occurred in the 2 extreme situations (frontal and oligotrophic Mediterranean) using $20 \mathrm{nM}$ additions. Leucine uptake was thus converted into bacterial production based on a conversion factor of $1.5 \mathrm{~kg} \mathrm{C} \mathrm{mol}{ }^{-1}$ of incorporated leucine (Kirchman 1993). Daily bacterial production was calculated as 24 times the hourly rate. Variability between duplicate samples was, on average, $7 \%$.

Factors limiting bacterial production and growth capacity. Six $500 \mathrm{ml}$ Nalgene polycarbonate bottles were preliminary rinsed overnight with $10 \% \mathrm{HCl}$, rinsed copiously with Milli-Q water and then rinsed with $0.8 \mu \mathrm{m}$-filtered seawater. They were then filled with $300 \mathrm{ml}$ of $<0.8 \mu \mathrm{m}$-filtered seawater (polycarbonate filter), and 5 bottles were amended as follows: $\mathrm{N}$ with nitrate $\left(\mathrm{NaNO}_{3}, 1 \mu \mathrm{M}\right.$ final conc.), $\mathrm{P}$ with phosphate $\left(\mathrm{NaH}_{2} \mathrm{PO}_{4}, 0.2 \mu \mathrm{M}\right.$ final conc.), G with glucose (D-glucose, $6 \mu \mathrm{M} \mathrm{C}$ final conc.), NP with a combination of nitrate and phosphate and NPG with a combination of nitrate, phosphate and glucose. Nutrients were not added to the control (Co). The samples were kept in the dark and bacterial production was measured 36 and $72 \mathrm{~h}$ after amendment, using the same protocol as for the vertical profiles. This procedure was repeated at 1 depth per site within the surface layer (between 5 and $10 \mathrm{~m}$ : Sites $3,4,5,6)$ and at the depth of the Tchl $a$ maximum at Sites $7(19 \mathrm{~m})$ and 8 (42 m). Growth capacity (i.e. the capacity to develop in bulk DOC in the 
absence of other fast-regenerating resources) was estimated as time-integrated bacterial production in the control after $72 \mathrm{~h}$ incubation. Growth capacity was calculated for all enrichments and expressed relative to the control (relative growth capacity).

Ectoaminopeptidase activity. Ectoaminopeptidase activity was estimated using the fluorogenic substrate L-leucine-4-methyl-7-coumarinylamid (MCA-leu). Potential ectoaminopeptidase activity (PEA) was measured at a final concentration of $200 \mu \mathrm{M}$. Using concentration kinetics, we occasionally checked that the $200 \mu \mathrm{M}$ additions enabled maximum rates to be attained. MCA-leu was added to duplicate $20 \mathrm{ml}$ samples, and incubated in the dark at in situ temperature. Aliquots $(3 \mathrm{ml})$ were subsampled every $2 \mathrm{~h}$. MCA fluorescence was read on a spectrofluorometer (TKO Hoefer) calibrated with MCA standard solutions at 5 time-points. The results were expressed in nmol $\mathrm{l}^{-1}$ $\mathrm{h}^{-1}$ (Hoppe et al. 1998). Variability between duplicate samples averaged $13 \%$.

Incorporation of amino acids. The potential uptake of amino acids (assimilation + respiration) was estimated by the addition of a ${ }^{14} \mathrm{C}$ amino acid mixture (Amersham, specific activity $52 \mathrm{mCi} \mathrm{mmol} \mathrm{C}^{-1}$ ) at $200 \mathrm{nM}$ final concentration. The radiolabelled amino acids were added to $20 \mathrm{ml}$ duplicates and a formalinkilled control. Samples were incubated in the dark for $2 \mathrm{~h}$ at in situ temperature; incubations were stopped by the addition of formalin ( $1 \%$ final conc.) buffered with saturating sodium tetraborate. After fixation, samples were filtered through $0.2 \mu \mathrm{m}$ polycarbonate Nuclepore filters, previously rinsed 3 times with $0.2 \mu \mathrm{m}$-filtered seawater. Treatment of the filtrates for the recovery of the respired fraction of amino acids is detailed in Van Wambeke et al. (2002a). Variability between duplicate samples averaged $14 \%$.

\section{RESULTS}

\section{Hydrological and hydrodynamic features}

During Leg 1 of 'Almofront 2' cruise, the jet-frontgyre system of the AOF was stationary (Y. Gratton pers. comm.), with the center of the eddy near $1.7^{\circ} \mathrm{W}$, $35.9^{\circ} \mathrm{N}$ (current map is presented in Cussatlegras et al. 2001). During the second leg of the cruise, the meander-gyre system slowly moved ca. $90 \mathrm{~km}$ eastwards along $36^{\circ} \mathrm{N}$, between 22 December $\left(1.3^{\circ} \mathrm{W}\right)$ and 16 January $\left(0.6^{\circ} \mathrm{W}\right.$, Fig. 1a). Consequently, the sites were chosen according to their hydrodynamic features and were relocated in an idealized jet-gyre structure (Fig. 1b), as if they had been studied simultaneously. The technique used to locate the sites in the schematic structure was based on the amplitude and direction of the currents and the depth of the pycnocline, as observed from the density profiles (Figs. 2 \& 3). Fig. 2 shows CTD profiles revealing a low intra-site variability associated with greater inter-site variability in density profiles. The pycnoclines deepened from Site 2 to Sites 3 and 6 (Figs. $2 \& 3$ ). Sites 8 and 2 were located in Mediterranean waters, with surface salinities greater than 37.5 and temperatures lower than $16^{\circ} \mathrm{C}$. However, Site 2 was located 2 miles from the intense surface-salinity front and could have been influenced by the proximity of the Atlantic jet, leading to a small change in the surface density and a possible fertilization by upwelled water induced by the secondary circulation associated with jet dynamics. Such fertilization near the jet has been previously observed (Videau et al. 1994). Site 7 was in the surface density front, on the left side of the jet. Sites 4 and 5 were on the left and right hand-sides of the jet core, respectively. Site 1 was similar to Site 5, but located upstream of the crest meander, as can be deduced from the northward direction of the flow. Sites 3 and 6 were in intermediate positions between the right side of the jet and the center of the AAG, but Site 3 was also slightly upstream of the crest (Fig. 1b).

The surface-density front, along the northern part of the jet flow, is the borderline between the highdensity $\left(>27.5 \mathrm{~kg} \mathrm{~m}^{-3}\right.$ ) Mediterranean surface waters having a long residence time, and the 'new' lightdensity $\left(<27.5 \mathrm{~kg} \mathrm{~m}^{-3}\right)$ Modified Atlantic Water continually arriving from the Atlantic Ocean through the Gibraltar Strait. This surface front is shown in Fig. 3, at the surface of the water column, as a density gap $\left(27.5 \mathrm{~kg} \mathrm{~m}^{-3}\right.$ ) between Mediterranean Sites 2 and 8 , and the other sites influenced by Atlantic waters. The positions of the sites on the virtual transect were also established by observing the depth of the pycnocline (Table 1, Fig. 3), shallower in Mediterranean waters (Sites 2 and 8), and then deepening from Modified Atlantic Waters to the center of the AAG (Sites 7, 4, 1, 5, 3 and 6). Site 6 notably exhibited a mixed layer which was not as homogenous as other sites in the AAG (Figs. $2 \& 3$ ). The depth of the $27.5 \mathrm{~kg} \mathrm{~m}^{-3}$ isopycne was used to delineate Mediterranean and Atlantic water masses and their corresponding biological variables and will hereafter be referred to as the 'density criteria'. This method of examining data can indicate the potential for possible lateral transfer of carbon and matter between the jet and eddy (Prieur \& Sournia 1994). Such transfer must occur along the slopes of the isopycnes, as vertical transfer through the strong density gradient (around $27.5 \mathrm{~kg}$ $\mathrm{m}^{-3}$ ) is weak. At the Mediterranean sites, we took the depth of the $28.5 \mathrm{~kg} \mathrm{~m}^{-3}$ isopycne to be representative of the borderline between surface and subsurface waters (Fig. 3). 

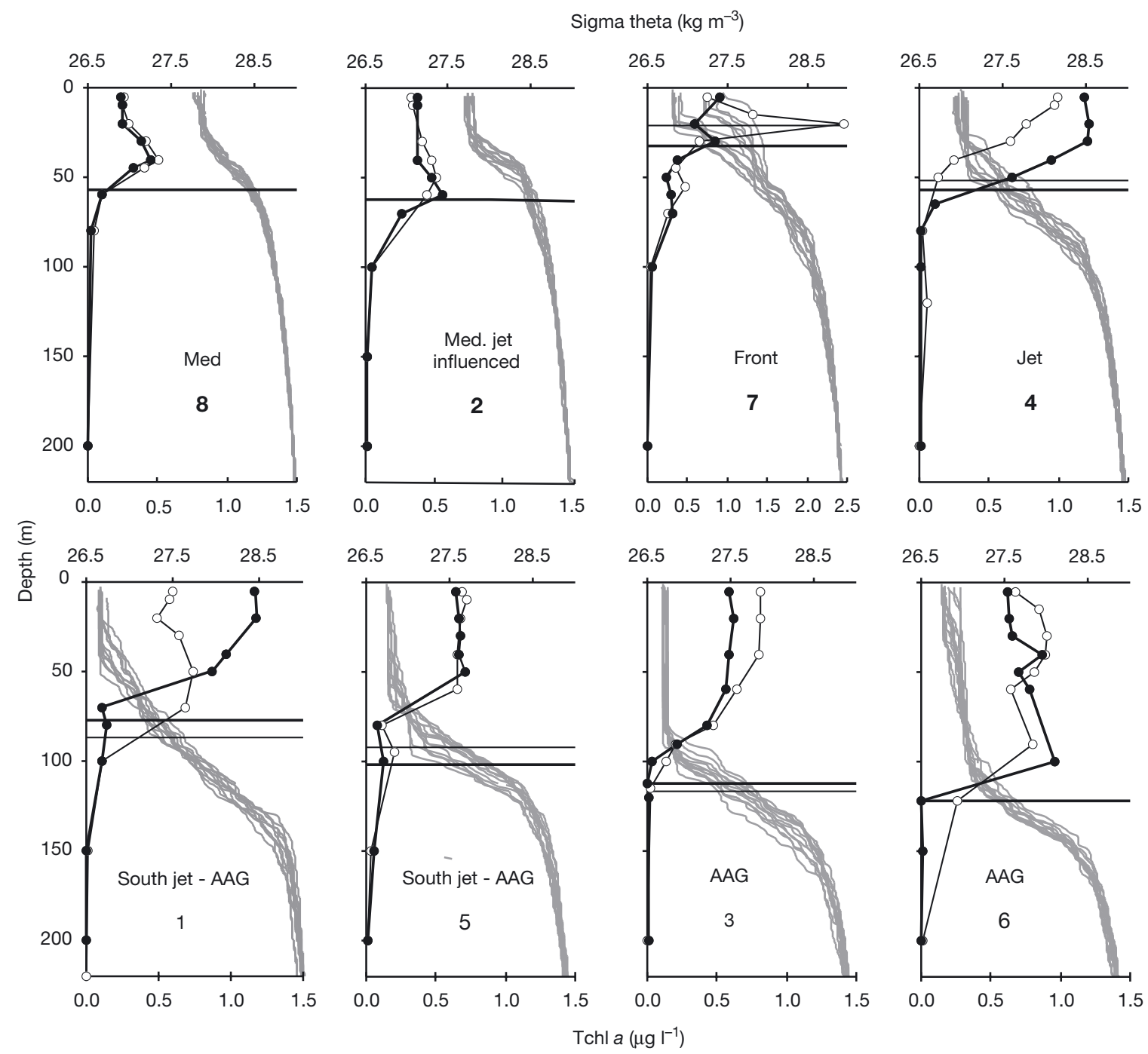

Fig. 2. Vertical profiles of sigma theta (grey lines) and total chl a (Tchl $a_{\text {; }}$ black lines and circles). All conductivity temperature depth (CTD) casts studied during the $36 \mathrm{~h}$ that each site was occupied are plotted (approx. 1 cast every $3 \mathrm{~h}$, from 04:00 h the first day to 16:00 $\mathrm{h}$ the second day). Thin line and open circles: CTD sampled at noon the first day, bold lines and closed circles: CTD sampled at noon the second day. Horizontal bars, following the same code, represent the depth of the density criteria of these 2 CTDs (i.e. the depth of $27.5 \mathrm{~kg} \mathrm{~m}^{-3}$ isopycne for Sites 7, 4, 1, 5, 3 and 6 and $28.5 \mathrm{~kg} \mathrm{~m}^{-3}$ isopycne for Sites 2 and 8, see 'Results' and Table 1). Where there is only 1 bar, the depth is equal for both CTDs. For convenience, all sites are presented in the following order: 2, 8 (Mediterranean sites), 7 (front), 4 (center of the jet), 1, 5 (south of the jet) 3, 6 (related to the AAG). Note the differing scale bar for Tchl $a$ at Site 7 . AAG: Atlantic anticyclonic gyre

\section{Biomasses}

\section{Autotrophs}

The vertical profiles (0 to $200 \mathrm{~m}$ ) of total chl a reveal 3 main features: (1) profiles were reproducible within each site despite a $24 \mathrm{~h}$ delay separating the 2 CTD casts; (2) maximum values of Tchl a were recorded at the front (Site 7) and minimum values in Mediterranean waters (Sites 2 and 8); (3) the shape of the profiles reflected the hydrodynamic conditions at the sites, with an increase in the thickness of the layer exhibiting higher values of Tchl $a$, from the front-jet (Sites 7 and 4 ) to the AAG (Site 6), where Tchl a decreased only below $100 \mathrm{~m}$ (Fig. 2). At the front (Site 7) there was a decrease in maximum Tchl a between the first and second day of sampling (from 2.4 to $0.9 \mu \mathrm{g}^{-1}$ ). However, this decrease may reflect a change in water masses as the sediment traps clearly drifted towards the jet core during occupation of Site 7 . This is demonstrated by the 2 sets of density profiles which are separated by a shift in surface density (Fig. 3). Lower values 
Table 2. Integrated total chlorophyll a (Tchl a), microbial standing stocks and bacterial production (0 to $200 \mathrm{~m})$, data obtained at the conductivity temperature depth (CTD) casts listed in Table 1. BB: heterotrophic bacterial biomass, HNAN: heterotrophic nanoflagellate biomass, BP: bacterial production

\begin{tabular}{|ccccc|}
\hline Site & $\begin{array}{c}\text { Tchl } a \\
\mathrm{mg} \mathrm{m}^{-2}\end{array}$ & $\begin{array}{c}\text { BB } \\
\mathrm{mmol} \mathrm{C} \mathrm{m}^{-2}\end{array}$ & $\begin{array}{c}\text { HNAN } \\
\mathrm{mmol} \mathrm{C} \mathrm{m}^{-2}\end{array}$ & $\begin{array}{c}\mathrm{BP} \\
\mathrm{mmol} \mathrm{C} \mathrm{m}^{-2} \mathrm{~d}^{-1}\end{array}$ \\
\hline 8 & 24 & 97 & 11 & 4.3 \\
& 21 & 59 & 10 & 4.6 \\
2 & 37 & 133 & 22 & 5.8 \\
& 35 & 123 & 23 & 5.8 \\
7 & 63 & 107 & 16 & 12.1 \\
& 47 & 109 & 16 & 10.4 \\
4 & 38 & 156 & 33 & 8.4 \\
& 63 & 152 & 37 & 8.2 \\
1 & 60 & 165 & 28 & 8.6 \\
& 71 & 159 & 29 & 11.7 \\
5 & 58 & 172 & 34 & 9.1 \\
& 54 & 167 & 33 & 6.9 \\
3 & 65 & 175 & 52 & 7.6 \\
& 51 & 155 & 44 & 5.7 \\
6 & 98 & 175 & 49 & 14.5 \\
& 101 & 178 & 39 & 17.9 \\
& & & & \\
& & & &
\end{tabular}

were recorded at Mediterranean sites, with subsurface (40 $\mathrm{m}$ at Site 8, 50 to $60 \mathrm{~m}$ at Site 2) Tchl a values of up to $0.55 \mathrm{\mu g} \mathrm{l}^{-1}$ (Fig. 2).

The vertical distribution of Tchl a had a strong impact on the integrated values ( 0 to $200 \mathrm{~m}$, Table 2). Indeed, although the highest Tchl a concentrations were recorded in the surface layer at Sites 7 and 4 to the left of the jet, integrated Tchl a reached the highest levels in the AAG (Table 2). As expected, Mediterranean waters displayed the lowest integrated biomass, whereas similar intermediate values were recorded at Sites 7, 4, 1, 5 and 3. Such discrepancies between concentration profiles and 0 to $200 \mathrm{~m}$ integrated values resulting from hydrodynamic conditions underline the necessity for the 'normalization' of biological parameters when making inter-site comparisons. For most biological parameters, we calculated an 'average' value, which was calculated from the integrated values divided by the depth of the density criteria. 'Average' Tchl a decreased from Site 7 to Site 3 (AAG), from $0.97 \pm 0.21$ to $0.50 \pm 0.05 \mu \mathrm{g} \mathrm{l}^{-1}$, respectively. At Mediterranean Sites 2 and 8, the 'average' Tchl a gave the lowest values $\left(0.40\right.$ and $0.31 \mathrm{\mu g} \mathrm{l}^{-1}$, respectively, Fig. 4).

\section{Heterotrophs}

The vertical distribution of bacterial abundance also reflects the hydrological conditions. As with Tchl $a$, the

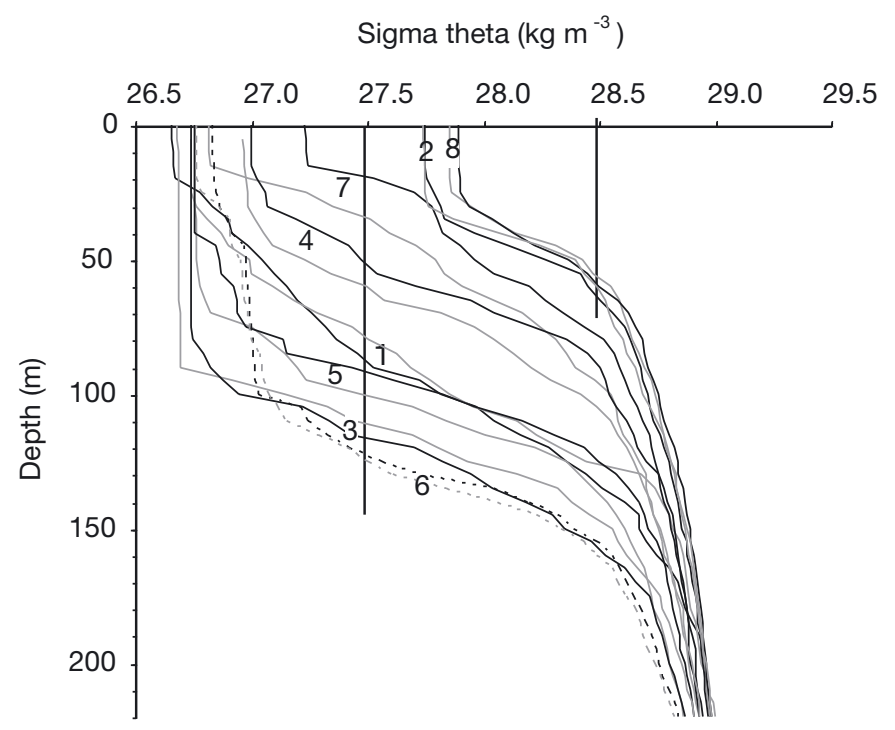

Fig. 3. Density depth profiles of both conductivity temperature depth (CTD) casts sampled at noon for microbial parameters (Table 1). For each site, the number of the site is situated between the 2 corresponding profiles ( 1 dark, 1 grey). The vertical bars indicate density criteria: sigma theta 27.5 and $28.5 \mathrm{~kg} \mathrm{~m}^{-3}$
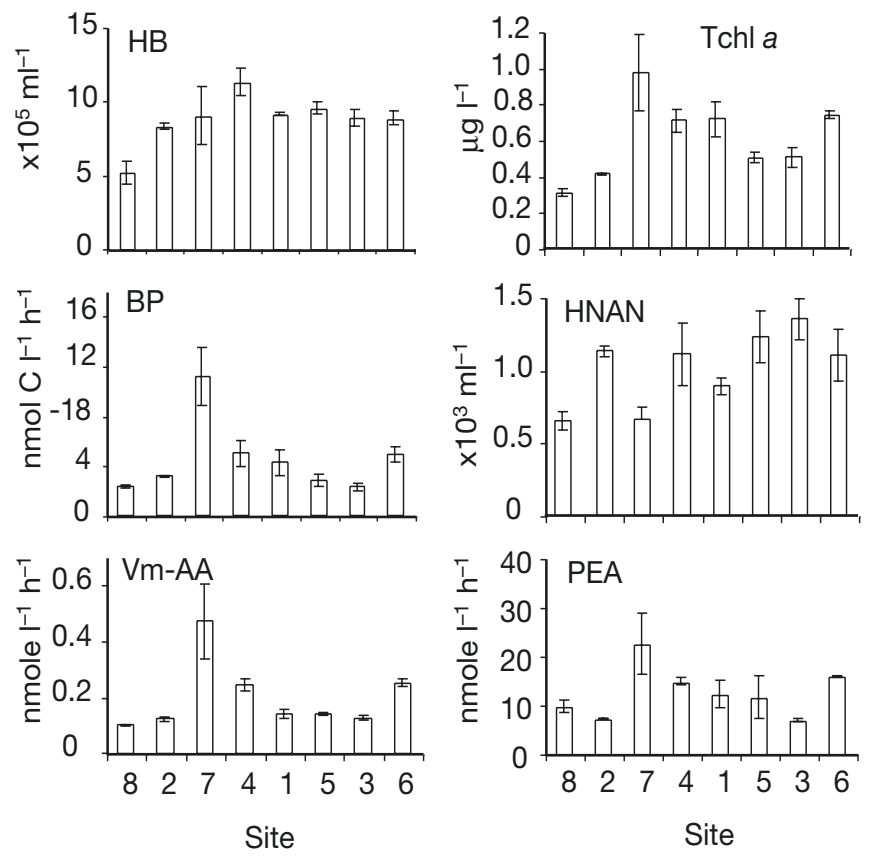

Fig. 4. Bacterial abundance $\left(\mathrm{HB}, \times 10^{5} \mathrm{ml}^{-1}\right)$, total chl a (tchl $a$, $\mu \mathrm{g} \mathrm{l}^{-1}$ ), bacterial production (BP, nmol $\left.\mathrm{C}^{-1} \mathrm{~h}^{-1}\right)$, nanoflagellate abundance $\left(\mathrm{HNAN}, \times 10^{3} \mathrm{ml}^{-1}\right)$, maximum uptake rates of amino acids (Vm-AA, nmole $\mathrm{l}^{-1} \mathrm{~h}^{-1}$ ), potential ectoaminopeptidase activity (PEA, nmole $\mathrm{l}^{-1} \mathrm{~h}^{-1}$ ). Data are calculated from integrated values divided by the depth of the density criteria (Table 1). Results are expressed as averages (of the 2 stations sampled at noon) and the length of the error bar is the difference between values obtained at the 2 stations 


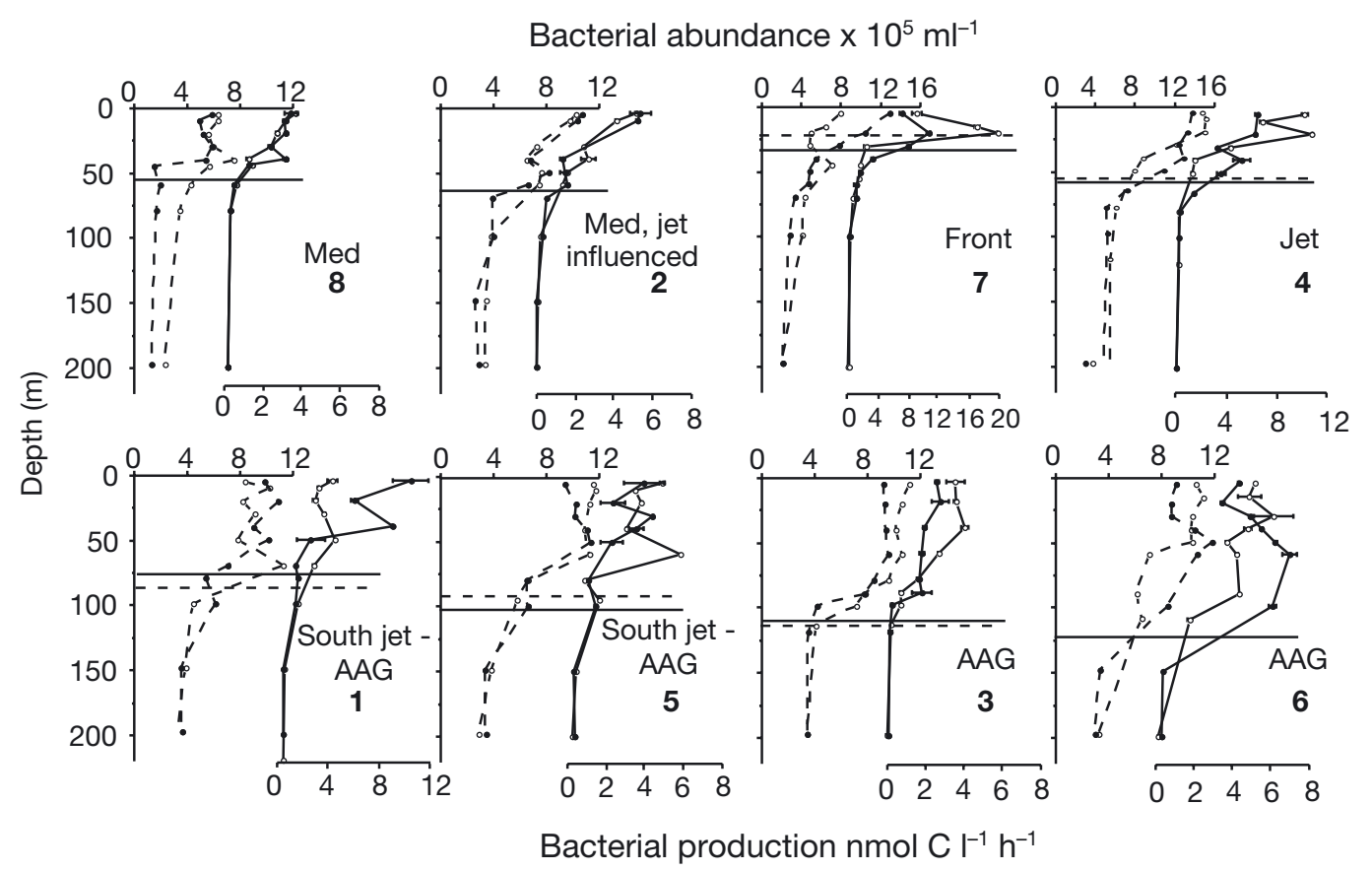

Fig. 5. Vertical profiles of bacterial abundance (dashed lines) and bacterial production (continuous lines). Open circles: first day at noon, closed circles: second day at noon. Numbers correspond to the sites. Horizontal bars indicate the depth of density criteria: dotted line is Day 1, continuous line is Day 2. Note varying scales. The length of the error bar associated with bacterial production data is the difference between duplicates. AAG: Atlantic anticyclonic gyre

profiles showed an increase in the depth were bacterial abundance could maintain high values, from the front and the jet (Sites 7 and 4) to the AAG (Site 3) where bacterial numbers began to decrease only below $100 \mathrm{~m}$ (Fig. 5). Maximum values for bacterial abundance were measured in the jet core (Site 4, up to $15 \times 10^{5}$ bacteria $\mathrm{ml}^{-1}$ ) and minimum values in Mediterranean waters (Site 8). The highest values for integrated bacterial biomass were found in the AAG (Sites 5, 3 and 6, Table 2) and the lowest in Mediterranean waters (Site 8). Using the density criteria described above, 'average' bacterial numbers were similar at most sites, ca. $10 \times 10^{5}$ bacteria $\mathrm{ml}^{-1}$, the exceptions being the Mediterranean sites where lower values were observed, and the jet center (Site 4) where values were higher (Fig. 4).

The abundance of heterotrophic nanoflagellates ranged from 0.13 to $2.69 \times 10^{3} \mathrm{ml}^{-1}$ in the 0 to $200 \mathrm{~m}$ layer. Integrated HNAN biomass varied from 10 to $52 \mathrm{mmol} \mathrm{C} \mathrm{m}{ }^{-2}$. They showed a greater range of variation (3-fold) than integrated bacterial biomasses (1.5-fold, Table 2) between Mediterranean and AAG waters. Using the density criteria, the lowest HNAN abundance was recorded at Mediterranean Site 8 ('average' $0.65 \times 10^{3} \mathrm{ml}^{-1}$ ) and maximum in the AAG (Site 3, 'average' $1.35 \times 10^{3} \mathrm{ml}^{-1}$, Fig. 4). Peaks of bacteria and nanoflagellates did not coincide. The number of bacteria per nanoflagellate (calculated using the ratio of 'average' values based on density criteria) ranged from 1420 bacteria per flagellate at Site 7 to 666 at Site 3. The HNAN biomass represented $14 \%$ of the bacterial biomass at the front (Site 7) and $30 \%$ in the AAG (Site 3).

\section{Bacterial production}

The vertical profiles of BP within a site were reproducible over the $24 \mathrm{~h}$ interval, with 2 exceptions, Sites 7 and 1 (Fig. 5). At Site 7, a greater variability between the 2 CTDs sampled at noon was observed for density and Tchl a profiles (Fig. 2). At Site 1, although density profiles were homogenous (Figs. 2 \& 3), both $\mathrm{BP}$ and Tchl a were higher over the first $30 \mathrm{~m}$ on the second day of sampling (Figs. $2 \& 5$ ). Within the surface layers, the lowest values for BP were measured in Mediterranean waters (Site 8) and in the AAG (Site 3),

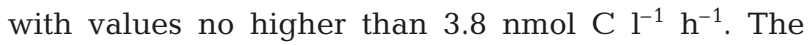
highest values were recorded the first day of sampling

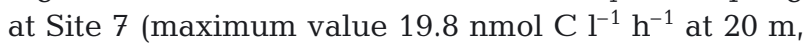
Fig. 5). Vertical profiles of BP were characterized by a near surface maximum (Mediterranean sites) or subsurface maximum (Site 7). There was an increase in the depths where elevated BP values could still be recorded, from the center of the Atlantic jet (Site 4), to the right of the jet, and up to Site 6, where values 


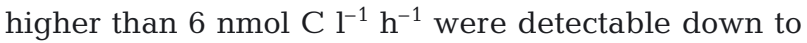
$100 \mathrm{~m}$. BP at the front (Site 7) was so strong in the surface layers that the integrated values down to $200 \mathrm{~m}$ were still high. Only at Site 6 (AAG) did integrated values overcome the BP values in the front (Table 2). Taking into account the 'average' values based on the density criteria, BP at Site 7 is double that of the other sites (Fig. 4).

\section{DOC and bacterial growth capacity}

DOC concentrations ranged from 48 to $87 \mu \mathrm{M}$ in the 0 to $200 \mathrm{~m}$ layer (raw data not shown). Integrated DOC values were lowest at Sites 2 and 6, and highest at Site 1 (Table 3). As with other parameters, a large difference in DOC was observed at Site 7 between the first and the second day of sampling (11880 and $14040 \mathrm{mmol} \mathrm{C} \mathrm{m}^{-2}$, respectively, Table 3). Assuming a value of $53 \mu \mathrm{M}$ for refractory DOC (taken as the average for deep-sea DOC between 400 and $1000 \mathrm{~m}$, Sempéré et al. 2003), the excess-DOC pool in the surface layer is calculated, and processed to compute an 'average' value for each site (based on density criteria, Fig. 6a). Excess-DOC ranged from 12 to $22 \mu \mathrm{M}$ C, with maximum values at Mediterranean Site 8 and AAG-jet boundaries (Sites 1 and 5), and minimum values at the front (Site 7), the left side of the jet (Site 4) and at Site 6.

Table 3. Integrated dissolved organic carbon (DOC) stocks (0 to $200 \mathrm{~m}$ ). Range of concentrations obtained from the surface to a threshold (TH) depth, and range obtained from that depth to $200 \mathrm{~m}$. This depth corresponds to the density $28.5 \mathrm{~kg} \mathrm{~m}^{-3}$ for Sites 8 and 2, and $27.5 \mathrm{~kg} \mathrm{~m}^{-3}$ for other sites (see Table 1). ns: not sampled. Site: code of the site. Data obtained at the conductivity temperature depth (CTD) casts listed in Table 1

\begin{tabular}{|ccccc|}
\hline $\begin{array}{c}\text { Site } \\
8\end{array}$ & $\begin{array}{c}\text { DOC } \\
\mathrm{mmol} \mathrm{m}^{-2}\end{array}$ & $\begin{array}{c}\text { TH depth } \\
\mathrm{m}\end{array}$ & $\begin{array}{c}\text { DOC range } \\
0-\mathrm{TH}(\mu \mathrm{M})\end{array}$ & $\begin{array}{c}\text { DOC range } \\
\text { below TH }(\mu \mathrm{M})\end{array}$ \\
\hline \multirow{2}{*}{$\begin{array}{c}14500 \\
\mathrm{~ns}\end{array}$} & 11680 & 57 & $75-83$ & $62-73$ \\
& 12780 & 62 & $61-70$ & $52-56$ \\
7 & 11880 & 21 & $60-71$ & $55-71$ \\
& 14040 & 32 & $66-72$ & $51-62$ \\
4 & 13070 & 52 & $61-76$ & $49-79$ \\
& 12690 & 57 & $50-72$ & $52-71$ \\
1 & 15550 & 87 & $73-81$ & $59-79$ \\
& 13380 & 77 & $66-81$ & $59-63$ \\
5 & 12700 & 92 & $52-83$ & $53-54$ \\
& 12710 & 102 & $59-79$ & $58-65$ \\
3 & 11640 & 117 & $55-67$ & $54-57$ \\
& 15500 & 112 & $74-87$ & $65-82$ \\
6 & 12150 & 122 & $64-71$ & $48-61$ \\
& 12430 & 122 & $60-74$ & $58-62$ \\
& & & & \\
\hline
\end{tabular}

The growth capacity of bacteria was estimated from the increase in BP over $72 \mathrm{~h}$ in $<0.8 \mu \mathrm{m}$ filtered seawater incubated in the dark. An increase in BP was observed, and was variable depending on the site (Fig. 6b). In Mediterranean waters (Site 8 at $42 \mathrm{~m}$ ), the front (Site 7 at $19 \mathrm{~m}$ ) and the AAG (Site 6 at $5 \mathrm{~m}$ ), there was a small increase in BP (ca. $1 \mu$ mol C $\mathrm{l}^{-1}$ over $72 \mathrm{~h}$ ), whilst at the jet (Site 4 at $10 \mathrm{~m}$ ), the south jet (Site 5 at $10 \mathrm{~m}$ ) and the other AAG site (Site 3 at $10 \mathrm{~m}$ ), this increase was between 3 and 4 times greater.

Nutrient amendments carried out at Sites 4 (10 m), 5 $(10 \mathrm{~m}), 3(10 \mathrm{~m})$ and $6(5 \mathrm{~m})$, using different nutrient additions, alone or in combinations, did not stimulate bacterial production anymore than the control (Fig. 7). At Mediterranean Site 8 (42 m), there was an increase in growth capacity following the addition of $\mathrm{G}$ and NPG over a $72 \mathrm{~h}$ period (1.4 and 2.0 times greater than the control, respectively). At the front (Site 7 at $19 \mathrm{~m}$ ), following P, NP and NPG additions the growth capacities were 1.4, 1.6 and 1.7 greater than in the control, respectively. The mean relative growth capacity
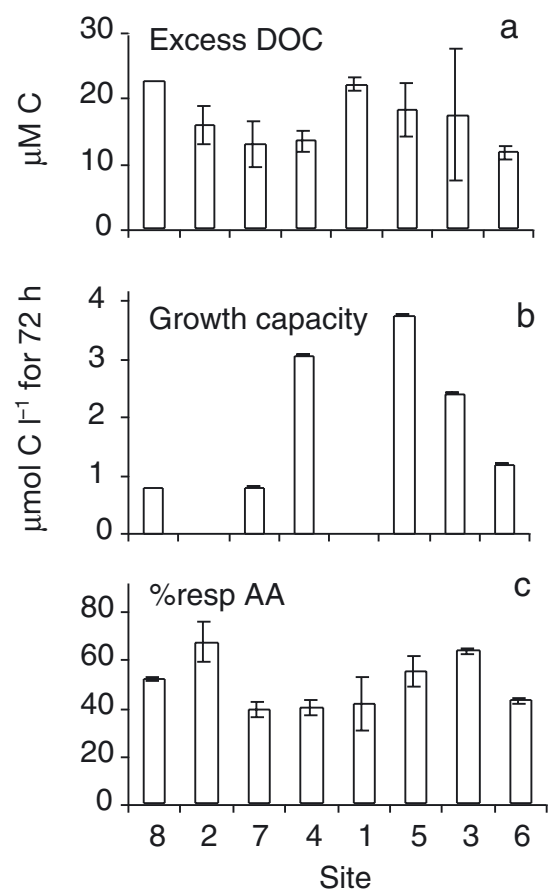

Fig. 6. (a) Excess dissolved organic carbon (DOC, $\mu \mathrm{M})$. DOC is calculated as total organic carbon (TOC) - particulate organic carbon (POC), and excess DOC is calculated from DOC data minus average deep layer DOC, taken as $53 \mu \mathrm{M}$. Averages and errors are calculated as in Fig 4 . There is no error bar for excess DOC at Site 8, as only 1 TOC profile was taken. (b) Growth capacity of heterotrophic bacteria in $0.8 \mu \mathrm{m}$ filtrates. Results expressed in time-integrated bacterial production after $72 \mathrm{~h}$ of incubation (nmole $\mathrm{Cl}^{-1}$ for $72 \mathrm{~h}$ ). This experiment included Sites: $8(42 \mathrm{~m}), 7(19 \mathrm{~m}), 4(10 \mathrm{~m}), 5(10 \mathrm{~m}), 3$ $(10 \mathrm{~m})$ and $6(5 \mathrm{~m})$. (c) Percentage of amino acids respired, averages and errors are calculated as in Fig. 4. AA: amino acids 


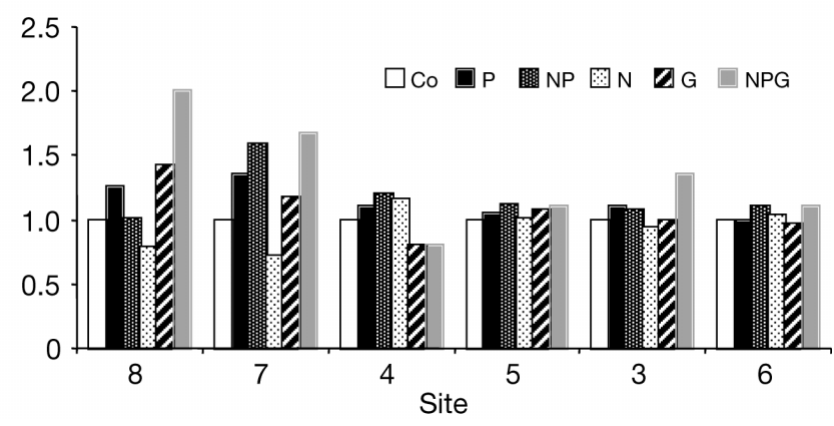

Fig. 7. Enrichment experiment. Results expressed as growth capacities over $72 \mathrm{~h}$, relative to the control which was not enriched, and therefore set to 1 for all experiments. Co: control, $\mathrm{P}:$ + phosphate, NP: + nitrate + phosphate, N: + nitrate, G: + glucose, NPG: + nitrate + phosphate + glucose

obtained from a given enrichment (N, P or G), alone or in combination, compared to the mean of the other ones not including it, were statistically different for glucose at Site $8(p=0.04)$ and phosphate at Site 7 ( $p=0.02$, Student's $t$-test), and confirmed these results.

\section{Ectoaminopeptidase activity and amino acid utilization}

Potential rates of ectoaminopeptidase activity (PEA) ranged from 0.05 to $42.8 \mathrm{nmol}$ leu hydrolyzed $\mathrm{l}^{-1} \mathrm{~h}^{-1}$ and maximum uptake rates of amino acids (Vm-AA) from 0.01 to $0.95 \mathrm{nM} \mathrm{h}^{-1}$ (raw data set not shown). Using all sites and data, Spearman rank correlation coefficients between Vm-AA, PEA and BP ranged from 0.82 to 0.92 (raw data, $\mathrm{n}=82$ to 96 depending on parameter, $\mathrm{p}<0.001)$. These correlations were obtained using a large range of values, including the deep layers down to $200 \mathrm{~m}$. However, examination of 'average' values, based on density criteria, showed a different evolution of the parameters along the virtual transect from the left side of the jet to the AAG (Fig. 4). 'Average' BP and maximum uptake rates of amino acids (Vm-AA) decreased simultaneously from site 7 (left side of the jet) to Site 3 (related to the AAG). There was a decrease by a factor ca. 0.5 at Site 4 (jet core) and 0.2 at Site 3. In contrast, 'average' values of maximum ectoaminopeptidase activity (PEA) decreased to a lesser extent from Site 7 through to Site 4 (decrease by a factor of 0.66), and to Site 3 (decrease by a factor of 0.31). Contrary to these general trends, the generation time of the bacterial population (calculated as $\ln (2) \times \mathrm{BB} / \mathrm{BP}$ of 'averages' presented in Fig. 4) increased from $3.2 \mathrm{~d}$ at Site 7 (left side of the jet) to $8.4 \mathrm{~d}$ at Site 4 (jet core). The maximal generation time was reached in the AAG (14.2 d at Site 3). The percentage of amino acids respired at saturating concentrations increased from Site 7 (39\%) to Site 3 (63\%, Fig. 6).

\section{Euphotic zone processes: photosynthesis/ respiration/heterotrophy}

Site 8 represented typical Mediterranean waters and was the only site to exhibit significant net heterotrophy (NCP $39 \mathrm{mmole}_{2} \mathrm{~m}^{-2} \mathrm{~d}^{-1}$ ). This is also observed when comparing values of DCR (50.2 mmol C m $\mathrm{m}^{-2} \mathrm{~d}^{-1}$ ) and particulate primary production $\left(\mathrm{PP},{ }^{14} \mathrm{C}\right.$-based, equal to $6.4 \mathrm{mmol} \mathrm{C} \mathrm{m}^{-2} \mathrm{~d}^{-1}$, all values integrated at the euphotic zone, Table 4). Due to the variability in oxygen measurement errors, NCP was not significantly different from zero at Sites 2, 5 and 3. Significant net autotrophy $(\mathrm{NCP}>0)$ was found in the front (Site 7), within the jet (Sites 4 and 1) and at Site 6. Both NCP and PP values reached their maximum at Site $4\left(50 \mathrm{mmole}_{2} \mathrm{~m}^{-2} \mathrm{~d}^{-1}\right.$ and $48 \mathrm{mmol} \mathrm{C} \mathrm{m}^{-2} \mathrm{~d}^{-1}$, respectively). DCR ranged between 17 (Site 1) and 57 (Site 5) $\mathrm{mmol} \mathrm{C} \mathrm{m}^{-2} \mathrm{~d}^{-1}$ and BP ranged between 2.3 (Mediterranean, Site 8) and 10 (front, Site 7) mmol C m $\mathrm{m}^{-2} \mathrm{~d}^{-1}$. Greatest errors in NCP and DCR estimates were obtained at Site 5, where volumetric data also displayed high variability. BP in the euphotic zone corresponded to 11 to $24 \%$ of the particulate PP in the jet and the Atlantic gyre, whereas higher ratios were observed in the typical Mediterranean waters (Site 8, 43\%).

\section{DISCUSSION}

\section{Effect of mesoscale hydrological and hydrodynamic structures on bacterial biomass and production}

This study emphasises the similarity between the vertical distribution of chlorophyll, bacterial biomass and production and the density profiles (Figs. $2 \& 5$ ). Using the depth of the $27.5 \mathrm{~kg} \mathrm{~m}^{-3}$ isopycne to separate Atlantic from Mediterranean waters, we were able to assess the role of primary and secondary circulation of water masses on the bacterial parameters. This was characterized by an increase in BP in the upper Atlantic layer at the frontal site, and by the deepening of sustained biomass and production down to $100 \mathrm{~m}$ in the Atlantic anticyclonic gyre. Pedros-Alio et al. (1999) also used integrated BP values divided by the integration depth to compare data with different hydrodynamic characteristics. The analysis of biological parameters using the scale of hydrodynamical features is useful when describing bacterial activity in relation to hydrology.

There is an increase in bacterial and primary production in frontal areas, irrespective of the frontal origin, i.e. geostrophic or haline fronts and geographical localization (Ducklow 1986, Kirchman et al. 1989, Fernandez et al. 1994, Videau et al. 1994, Christaki et al. 1999, Pedros-Alio et al. 1999, Cho et al. 2001, Moran et 
al. 2001). The Almeria-Oran frontal system was studied in spring (Almofront 1 cruise, 1991) and winter (the present study). In the frontal zone, chlorophyll stocks were similar for both seasons (ca. $50 \mathrm{mg} \mathrm{m}^{-2}$ ). In winter, values for PP were 8 times lower in Mediterranean waters, 3 times lower in the front and jet core and 2 times lower in the AAG when compared to spring values (Videau et al. 1994). This showed the importance of the frontal zone in terms of PP, even during winter.

At Mediterranean Site 8, integrated BP (0 to $150 \mathrm{~m}$ layer: 3.9 to $4.2 \mathrm{mmol} \mathrm{C} \mathrm{m}^{-2} \mathrm{~d}^{-1}$ ) was 4 times lower in winter than in spring $\left(16 \mathrm{mmol} \mathrm{C} \mathrm{m} \mathrm{m}^{-2} \mathrm{~d}^{-1}\right.$, Fernandez et al. 1994). Such differences could not arise from a temperature effect, as surface temperatures ranged from 15.3 to $16.0^{\circ} \mathrm{C}$ in January, and from 16.3 to $17.3^{\circ} \mathrm{C}$ in May. These seasonal variations in BP have been previously observed in Mediterranean waters (Lemée et al. 2002). In the dynamic area of the jet and in the AAG, integrated bacterial production was similar for the 2 seasons: from 12.2 to $13.4 \mathrm{mmol} \mathrm{C} \mathrm{m}^{-2} \mathrm{~d}^{-1}$ in spring (Fernandez et al. 1994) and from 5.5 to $17.5 \mathrm{mmol} \mathrm{C} \mathrm{m}{ }^{-2} \mathrm{~d}^{-1}$ in the 0 to $150 \mathrm{~m}$ layer in winter, implying that the hydrodynamic conditions supported more stable BP. The differences in PP were greater than the differences in BP between winter and spring. A seasonal trend was described in the north-west Mediterranean (Van Wambeke et al. 2002b) and along a transect from the Spanish coast to the Balearic Islands (Pedros-Alio et al. 1999). In general, our results agree with previous studies where the variability in $\mathrm{BP}$, relative to $\mathrm{PP}$, is higher in the frontal areas (Pedros-Alio et al. 1999, Cho et al. 2001) than in the oligotrophic waters of the open sea (Ducklow \& Carlson 1992). Many assumptions based on conversion factors and methodologies influence the absolute value of the BP:PP ratio, which we used here for relative purposes (Pedros-Alio et al. 1999, Ducklow et al. 2002). Although we obtained some high BP:PP ratios (up to $38 \%$ at the frontal site), suggesting net heterotrophy (Del Giorgio \& Duarte 2002), only the Mediterranean site was found to be clearly net heterotrophic using oxygen-based measurements (net community production). Frontal systems could then support net autotrophy throughout the year, so compensating for periods of net heterotrophy in adjacent areas.

\section{Mesoscale impact on the microbial network}

Mediterranean waters

As observed by growth experiments on $0.8 \mu \mathrm{m}$ filtered sea-water, heterotrophic bacteria had a low growth capacity in Mediterranean water taken at the chlorophyll maximum layer (Site 8, 42 m, Fig. 6). As pre-filtration removes most phytoplankton cells and grazers, this suggests that the growth of in situ bacteria depends on fast-regenerating resources, originating from cells or particles $>0.8 \mu \mathrm{m}$. The enrichment experiments carried out on water taken from the chlorophyll maximum layer showed that BP was stimulated with the addition of glucose. This indicates a strong interdependency between heterotrophic bacteria and local primary producers in Mediterranean waters. This is substantiated by the importance of BP relative to PP at Site 8 (BP:PP ratio $43 \%$, Table 4 ). Contrary to this, high stocks of excess-DOC were found at Site 8 (Fig. 6), indicating that organic carbon is not a limiting factor, thus the heterotrophic bacteria should not have been stimulated by the glucose. However, there is some debate regarding the degree of lability of the excessDOC pool (Carlson 2002, Ducklow et al. 2002), and another hypothesis put forward to explain DOC accumulation is that a component other than labile carbon could be limiting BP in surface waters (Thingstad et al. 1997, Olsen et al. 2002). The enrichment experiment at Site 8 was carried out on water sampled from $42 \mathrm{~m}$ where the in situ $\mathrm{PO}_{4}$ concentration was $0.03 \mu \mathrm{M}$ but undetectable in the surface layers (P. Morin pers. comm.). It has been demonstrated that heterotrophic bacterial populations are strongly P-limited in surface waters, where $\mathrm{PO}_{4}$ concentrations are undetectable, and they then switch rapidly along the vertical profiles to a status of C-limitation during the stratification period (Van Wambeke et al. 2002a). Sala et al. (2002) also showed that factors limiting bacterial growth can change over the water column. Consequently, heterotrophic bacteria in the surface water of Site 8 could also be P-limited, which may explain the excess-DOC found at this site. This winter situation was possible because the water column was still stratified. During the first leg of the cruise, a low bacterial growth efficiency $(7 \%$, measured in a dilution culture experiment, Sempéré et al. in press) was recorded in surface Mediterranean waters. This is also indicated during the second leg of the cruise, with high values of DCR compared to BP measured at Site 8 (Table 4), respiration of bacteria representing a significant part of the DCR (Ducklow et al. 2000). Indeed, the nutrient deficiency induces an energy cost, reflected by a decrease in bacterial growth efficiency (Carlson \& Ducklow 1996) or by an increase in the fraction of amino acids respired (Van Wambeke et al. 2002a, Fig. 6).

\section{Atlantic waters}

Maximum bacterial production was observed at the front (Site 7), maximum bacterial abundance in the core of the jet (Site 4), and maximum nanoflagellate 
Table 4. Integrated bacterial production (BP), dark community respiration (DCR, oxygen based with $\mathrm{RQ}=0.8$ ), primary production (PP, ${ }^{14} \mathrm{C}$-based), net community production (oxygen based) and BP:PP ratios. Errors are integrated errors of volumetric data (SE for DCR and NCP, and variability within duplicates for BP). Integration depth corresponded to the euphotic zone. For BP and $\mathrm{PP}$, parameters were obtained from the noon conductivity temperature depth (CTD) casts listed in Table 1. For DCR and NCP, data were obtained from the CTD cast made just before the sunrise the second day of sampling

\begin{tabular}{|c|c|c|c|c|c|c|}
\hline Site & $\begin{array}{l}\text { Integration } \\
\text { depth }(\mathrm{m})\end{array}$ & 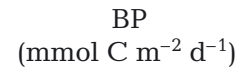 & $\begin{array}{c}\text { DCR } \\
\left(\mathrm{mmol} \mathrm{C} \mathrm{m}^{-2} \mathrm{~d}^{-1}\right)\end{array}$ & 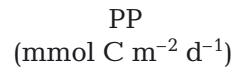 & $\begin{array}{c}\mathrm{NCP} \\
\left(\mathrm{mmol} \mathrm{O} \mathrm{m}^{-2} \mathrm{~d}^{-1}\right)\end{array}$ & $\begin{array}{c}\text { BP:PP } \\
(\%)\end{array}$ \\
\hline 8 & 61 & $\begin{array}{l}2.3 \pm 0.1 \\
2.8 \pm 0.1\end{array}$ & $50.2 \pm 7.4$ & 6.4 & $-39 \pm 19$ & 43 \\
\hline 2 & 55 & $\begin{array}{l}4.3 \pm 0.2 \\
4.4 \pm 0.3\end{array}$ & $18.1 \pm 4.4$ & 19.3 & $5 \pm 7$ & 22 \\
\hline 7 & 45 & $\begin{array}{c}10.0 \pm 0.3 \\
8.1 \pm 0.2\end{array}$ & $48.1 \pm 4.7$ & $\begin{array}{c}21.8^{\mathrm{a}} \\
21.0-30.1^{\mathrm{b}}\end{array}$ & $29 \pm 12$ & 38 \\
\hline 4 & 48 & $\begin{array}{l}7.2 \pm 0.2 \\
6.1 \pm 0.3\end{array}$ & $35.6 \pm 3.5$ & 48.2 & $50 \pm 8$ & 13 \\
\hline 1 & 48 & $\begin{array}{l}4.0 \pm 0.2 \\
9.1 \pm 0.6\end{array}$ & $17.3 \pm 11.4$ & 37.2 & $25 \pm 6$ & 24 \\
\hline 5 & 54 & $\begin{array}{l}4.9 \pm 0.1 \\
4.2 \pm 0.7\end{array}$ & $57.8 \pm 22.3$ & 35.8 & $1.5 \pm 26$ & 12 \\
\hline 3 & 56 & $\begin{array}{l}5.1 \pm 0.3 \\
3.3 \pm 0.3\end{array}$ & $23.4 \pm 5.5$ & 30.3 & $11 \pm 11$ & 11 \\
\hline 6 & 48 & $\begin{array}{l}6.1 \pm 0.6 \\
5.3 \pm 0.1\end{array}$ & $38.6 \pm 4.7$ & 32.8 & $36 \pm 3$ & 16 \\
\hline
\end{tabular}

abundance in the gyre (Site 3). This suggests varying degrees of substrate versus grazer control for bacterial and flagellate populations at the different sites (McManus \& Fuhrman 1990, Sanders et al. 1992, Gasol \& Vaqué 1993). Heinänen et al. (1995), during a study on a frontal system at the entrance of the Gulf of Finland, found that increasing bacterial abundance between hydrodynamic events did not affect heterotrophic flagellates. In this instance we focus on bacterial resources, as there are no direct estimates of grazing fluxes, making it difficult to discuss mesoscale effects on top-down control of bacterial biomass. Within the jet (Sites 4 and 5) and the AAG (Site 3), bacterial production was not stimulated by the addition of inorganic nutrients or glucose. This indicates that bacteria were not limited by any resource beyond $72 \mathrm{~h}$ of the experiment. In fact, enhanced growth capacities were observed (Fig. 7). There is an uncoupling between the production and consumption of 'fresh' DOC when dark incubations are performed in $0.8 \mu \mathrm{m}$-filtered seawater. 'Fresh' DOC production is considered, in this case, to be a particle-dependent source, such as phytoplankton excretion, sloppy feeding and the hydrolysis of detritus. Consequently, if the growth capacity in the $0.8 \mu \mathrm{m}$ filtered culture is high, the material present in the DOC pool is probably representative of in situ conditions, where production of labile DOC is higher than consumption processes (Carlson \& Ducklow 1996). On the other hand, high mesozooplankton standing stocks suggest the importance of secondary production in cropping primary production at the Atlantic sites (Youssara \& Gaudy 2001). These results agree with the lower BP:PP ratios obtained in this area. A weak coupling between local, instantaneous primary production and bacterial production suggests that bacteria alternatively use detritus-derived and DOC sources, which were either produced before sampling or were imported from elsewhere. The very short residence time of water masses in these hydrodynamic systems and the isopycnal transport observed (Claustre et al. 1994, Videau et al. 1994), indicates a lateral transfer. Low stocks of excess DOC were observed within the front and in the jet core (Sites 7 and $4,13 \mu \mathrm{M}$ ) but higher and more constant values were determined at the other sites, ranging from 16 to $22 \mu \mathrm{M}$. Increasing contribution of degraded by-products in the lipid fraction of particulate organic matter were observed in the AAG and along the $27.5 \mathrm{~kg} \mathrm{~m}^{-3}$ isopycne (Striby 2000). These observations suggest that hydrolysis of particles could occur within the gyre, leading to an increase in the DOC pool. Potential ectoaminopeptidase activity (PEA) decreased less sharply than bacterial production at Sites 4, 1 and 5, showing an increased dependence on polymeric DOC (Sala et al. 2002, Torréton et al. 
2002). The percentage of amino acid respiration also increased, indicating that bacteria had adapted to changes in the chemical status of the organic matter within the jet and AAG (Christian \& Karl 1995, del Giorgio \& Cole 1998).

\section{Conclusion}

In conclusion, the permanence of the frontal structure in the Alboran Sea clearly affects bacterial activity, and this study shows that a mesoscale approach can be used for studies on heterotrophic bacteria and other biological parameters. High or low values of bacterial biomass and production are explained by very different controlling factors, dependant on the hydrological dynamics of the sampling site. As a reference, the oligotrophic Mediterranean waters, still stratified in winter, showed bottom-up control of the bacterial population. Bacterial growth was probably limited by phosphorus availability within the surface layers, and by the labile carbon source, deriving from the primary producers, within the Tchl a maximum layer. Hence, bacterial growth efficiency was very low, excess-DOC accumulated in the surface and the BP:PP ratio was typically high. In the front, the upwelling field led to an increase in bacterial production and probably caused the uncoupling between bacteria and their predators. Due to the isopycnal transport, bacterial biomass produced in the front accumulated within the Atlantic jet. Within the jet-AAG boundaries, bacteria benefited from the accumulation of organic material (DOC and POC) produced in the front and the jet which derived from lateral advection. Bacterial populations were not limited by labile carbon, P or N. Finally, due to the horizontal export of DOC, detritus and living biomass, fronts, jets and their associated gyres should be considered together when attempting to solve carbon budgets and fluxes on a mesoscale, particularly when attempting to clarify situations where there is net heterotrophy or high BP:PP ratios (Ducklow et al, 2002). Meander/gyre systems are permanent features in open oceans and a front is crossed once or twice over a distance of 500 to $1000 \mathrm{~km}$ (Fedorov 1986). Assuming each is ca. $100 \mathrm{~km}$ wide, these jets must cover $1 / 5$ of the ocean surface. An adequate approach must be considered in the future for exploring such mesoscale variability, in order to assess the way the ecosystem functions in terms of organism distribution, relative activity and their control in relation to the fluxes of elements.

Acknowledgements. We thank B. Maroni for help in collecting samples. B. Mélis and H. Karayanni performed a large share of the microscopy. We thank S. Jacquet for providing us with picophytoplankton data, P. Morin for nutrient data,
J. Raunet and D. Taillez for CTD database, David Antoine for estimates of integrated primary production and associated errors, and T. Bentley for improving the English. Comments and suggestions by D. Kirchman and reviewers were helpful in revising this manuscript. This work was supported by the operation FRONTAL of the program PROOF of INSU-CNRS, France.

\section{LITERATURE CITED}

Allen JT, Smeed DA, Tintoré J, Ruiz S (2001) Mesoscale subduction at the Almeria-Oran front. Part 1: Ageostrophic flow. J Mar Syst 30:263-285

Babin M, Morel A, Gagnon R (1994) An incubator designed for extensive and sensitive measurements of phytoplankton photosynthetic parameters. Limnol Oceanogr 39: 694-702

Baldacci A, Corsini G, Grasso R, Manzella G, Allen JT, Cipollini P, Guymer TH, Snaith HM (2001) A study of the Alboran Sea mesoscale system by means of emprirical orthogonal function of decomposition of satellite data. J Mar Syst 29:293-311

Bode A, Barquero SM, Braun JG, Armas D (2001) Pelagic bacteria and phytoplankton in oceanic waters near the Canary Islands in summer. Mar Ecol Prog Ser 209:1-17

Bruyant F (2002) Variations circadiennes et spatiales de la photosynthèse: Etude dans différentes conditions hydrologiques et trophiques. $\mathrm{PhD}$ thesis, Université $\mathrm{P}$ et $\mathrm{M}$ Curie, Paris VI

Caron DA, Peele ER, Lim ER, Dennett MR (1999) Picoplankton and nanoplankton and their trophic coupling in surface waters of the Sargasso Sea South of Bermuda. Limnol Oceanogr 44:259-272

Carlson CA, Ducklow HW (1996) Growth of bacterioplankton and consumption of dissolved organic carbon in the Sargasso Sea. Aquat Microb Ecol 10:69-85

Cho BC, Park MG, Shim JH, Choi DH (2001) Sea-surface temperature and $f$ ratio explain large variability in the ratio of bacterial production to primary production in the Yellow Sea. Mar Ecol Prog Ser 216:31-41

Christaki U, Van Wambeke F, Dolan JR (1999) Nanoflagellates (mixotrophs, heterotrophs and autotrophs) in the oligotrophic eastern Mediterranean: standing stocks, bacterivory and relationships with bacterial production. Mar Ecol Prog Ser 187:297-307

Christian JR, Karl DM (1995) Bacterial ectoenzymes in marine waters: activity ratio and temperature responses in three oceanographic provinces. Limnol Oceanogr 40:1046-1053

Claustre H, Kerhervé P, Marty JC, Prieur L, Videau C, Hecq JH (1994) Phytoplankton dynamics associated with a geostrophic front: ecological and biogeochemical implications. J Mar Res 52:711-742

Claustre H, Fell F, Oubelkheir K, Prieur L, Sciandra A, Gentili B, Babin M (2000) Continuous monitoring of surface optical properties across a geostrophic front: biogeochemical inferences. Limnol Oceanogr 45:309-320

Cussatlegras AS, Geistdoerfer O, Prieur L (2001) Planktonic bioluminescence measurements in the frontal zone of Almeria-Oran (Mediterranean Sea). Oceanol Acta 24:239-250

del Giorgio PA, Cole JJ (1998) Bacterial growth efficiency in natural aquatic systems. Annu Rev Ecol Syst 29:503-541

del Giorgio P, Duarte C (2002) Respiration in the open ocean. Nature 420:379-384

Ducklow HW (1984) Geographical ecology of marine bacteria: physical and biological variability at the mesoscale. In: Klugand MJ, Reddy CA (eds) Current perpectives in 
microbial ecology. American Society for Microbiology, Washington, DC, p 22-32

Ducklow HW (1986) Bacterial biomass in warm core Gulf Stream ring 82B: mesoscale distribution, temporal changes, and production. Deep-Sea Res 33:1789-1812

Ducklow HW, Carlson CA (1992) Oceanic bacterial production. In: Marshall KC (ed) Advances in microbial ecology. Plenum Press, London, p 113-181

Ducklow HW, Dickson M, Kirchman DL, Steward G, Orchardo J, Marra J, Azam F (2000) Constraining bacterial production, conversion efficiency and respiration in the Ross Sea, Antarctica, January-February, 1997. Deep-Sea Res II 47:3227-3247

Ducklow HW, Kirchman DL, Anderson TR (2002) The magnitude of spring bacterial production in the North Atlantic Ocean. Limnol Oceanogr 47:1684-1693

Fedorov KN (1986) The physical nature and structure of oceanic fronts. Springer-Verlag, Berlin

Fernandez M, Bianchi M, Van Wambeke F (1994) Bacterial biomass, heterotrophic production and utilization of dissolved organic matter photosynthetically produced in the Almeria-Oran front. J Mar Syst 5:313-325

Fielding S, Crisp N, Allen JT, Hartman MC, Rabe B, Roe HS (2001) Mesoscale subduction at the Almeria Oran front. Part 2: biophysical interactions. J Mar Syst 30:287-304

Fukuda R, Ogawa H, Nagata T, Koike I (1998) Direct determination of carbon and nitrogen contents of natural bacterial assemblages in marine environments. Appl Environ Microbiol 64:3352-3358

Gasol J, Vaqué D (1993) Lack of coupling between heterotrophic nanoflagellates and bacteria. A general phenomenon across aquatic ecosystems? Limnol Oceanogr 38:657-665

Gérin C, Goutx M (1994) Iatroscan-measured particulate and dissolved lipids in the Almeria-Oran frontal system (Almofront-1, May 1991). J Mar Syst 5:343-360

Grout H, Sempéré S, Thill A, Calafat A, Prieur L, Canals M (2001) Morphological and chemical variability of colloids in the Almeria-Oran front in the Estern Alboran Sea (SW Mediterranean Sea). Limnol Oceanogr 46:1347-1357

Heinänen A, Kononen K, Kuosa K, Kuparinen J, Mäkelä K (1995) Bacterioplankton growth associated with physical fronts during a cyanobacterial bloom. Mar Ecol Prog Ser 116:233-245

Hoppe HG, Giesenhagen HC, Gocke K (1998) Changing patterns of bacterial substrate decomposition in a eutrophication gradient. Aquat Microb Ecol 15:1-13

Karner M, Fuks D, Herndl GJ (1992) Bacterial activity along a trophic gradient. Microb Ecol 24:243-257

Karrash B, Hoppe HG, Ulrich S, Podewski D (1996) The role of mesoscale hydrography on microbial dynamics in the northeast Atlantic: results of a spring bloom experiment. J Mar Res 54:99-122

Kirchman DL (1993) Leucine incorporation as a measure of biomass production by heterotrophic bacteria. In: Kemp PF, Sherr BF, Sherr EB, Cole JJ (eds) Handbook of methods in aquatic microbial ecology. Lewis Publishers, Boca Raton, FL, p 509-512

Kirchman D, Soto Y, Van Wambeke F, Bianchi M (1989) Bacterial production in the Rhône River Plume: effect of mixing on relationships among microbial assemblages. Mar Ecol Prog Ser 53:267-275

Legendre L, Rassoulzadegan F (1996) Food-web mediated export of biogenic carbon in oceans: hydrodynamic control. Mar Ecol Prog Ser 145:179-193

Lemée R, Rochelle-Newall E, Van Wambeke F, Pizay MD, Rinaldi P, Gattuso JP (2002) Seasonal variation of bacterial production, respiration and growth efficiency in the open
NW Mediterranean Sea. Aquat Microb Ecol 29:227-237

Lochte K, Pfannkuche O (1987) Cyclonic cold-core eddy in the eastern North Atlantic. Nutrients, phytoplankton and bacterioplankton. Mar Ecol Prog Ser 39:153-164

McManus GB, Fuhrman JA (1990) Mesoscale and seasonal variability of heterotrophic nanoflagellate abundance in an estuarine outflow plume. Mar Ecol Prog Ser 61:207-213

Moran XA, Taupier-Lepage I, Vasquez-Dominguez E, Ruiz S, Arin L, Raimbault P, Estrada M (2001) Physical-biological coupling in the Algerian Basin (SW Mediterranean): influence of mesoscale instabilities on the biomass and production of phytoplankton and bacterioplankton. DeepSea Res I 48:405-437

Morel A, Antoine D, Babin M, Dandonneau Y (1996) Measured and modeled primary production in the northeast Atlantic (EUMELI JGOFS program): the impact of natural variations in photosynthetic parameters on model predictive skill. Deep-Sea Res I 43:1273-1304

Olsen LM, Reinertsen H, Vadstein O (2002) Can phosphorus limitation inhibit dissloved organic carbon consumption in aquatic microbial food webs? A study of three food web structures in microcosms. Microb Ecol 43:353-366

Pedros-Alio C, Calderon-Paz JI, Guixa-Boixereu N, Estrada M, Gasol JM (1999) Bacterioplankton and phytoplankton biomass and production during summer stratification in the northwestern Mediterranean Sea. Deep Sea Res I 46: 985-1019

Prieur L, Sournia A (1994) 'Almofront 1' (April to May 1991): an interdisciplinary study of the Almeria-Oran geostrophic front, SW Mediterranean. J Mar Syst 5:187-203

Rodriguez J, Tintoré J, Allen JT, Blanco JM and 6 others (2001) Mesoscale vertical motion and the size structure of phytoplankton in the ocean. Nature 410:360-363

Sala M, Peters F, Gasol J, Pedros-Alio C, Marrasse C, Vaqué D (2002) Seasonal and spatial variations in the nutrient limitation of bacterioplankton growth in the northwestern Mediterranean. Aquat Microb Ecol 27:47-56

Sanders RW, Caron DA, Berninger UG (1992) Relationships between bacteria and heterotrophic nanoplankton in marine and fresh waters: an inter-system comparison. Mar Ecol Prog Ser 86:1-14

Sempéré R, Dafner E, Van Wambeke F, Lefèvre D and 5 others (2003) Distribution and cycling of total organic carbon across the Almeria-Oran front in the Mediterranean Sea. Implications for carbon cycling in the western basin. J Geophys Res 108:3361

Striby L (2000) Biogéochimie de la matière organique marine dans deux écosystèmes marins. Cas d'une structure physique unidimensionnelle verticale (Mer Ligure) et d'une structure physique frontale (Front Alméria-Oran). Variations spatio-temporelles de la fraction lipidique à petite échelle. PhD thesis, Aix-Marseille II

Thibault D, Gaudy R, Le Fèvre J (1994) Zooplankton biomass, feeding and metabolism in a geostrophic frontal area (Almeria-Oran Front, Western Mediterranean). Significance to pelagic food webs. J Mar Syst 5:297-311

Thingstad F, Hagstrom A, Rassoulzadegan F (1997) Accumulation of degradable DOC in surface waters: is it caused by a malfunctioning microbial loop? Limnol Oceanogr 42: 398-404

Torréton JP, Pages J, Talbot V (2002) Relationships between bacterioplankton and phytoplankton biomass, production and turnover rate in Tuamotu Atoll lagoons. Aquat Microb Ecol 28:267-277

Van Wambeke F (1995) Numération et taille des bactéries planctoniques au moyen de l'analyse d'images couplée à l'épifluorescence. Océanis 21:113-124 
Van Wambeke F, Christaki U, Giannakourou A, Moutin T, Souvemerzoglou K (2002a) Longitudinal and vertical trends of bacterial limitation by phosphorus and carbon in the Mediterranean Sea. Microb Ecol 43:119-133

Van Wambeke F, Heussner S, Diaz F, Raimbault P, Conan P (2002b) Small-scale variability in the coupling/uncoupling of bacteria, phytoplankton and organic carbon fluxes along the continental margin of the Gulf of Lions, North western Mediterranean Sea. J Mar Syst 33-34:411-429

Videau C, Sournia A, Prieur L, Fiala M (1994) Phytoplankton

Editorial responsibility: Otto Kinne (Editor),

Oldendorf/Luhe, Germany and primary production characteristics at selected sites in the geostrophic Almeria-Oran front system (SW Mediterranean Sea). J Mar Syst 5:235-250

Williams PJ LeB, Jenkinson NW (1982) A transportable microprocessor-controlled precise Winkler titration suitable for field station and shipboard use. Limnol Oceanogr 27: 576-584

Youssara F, Gaudy R (2001) Variations of zooplankton in the frontal area of the Alboran Sea (Mediterranean Sea) in winter 1997. Oceanol Acta 24:361-376

Submitted: November 26, 2003; Accepted: September 9, 2003 Proofs received from author(s): March 8, 2004 